\title{
Comparative Bioavailability and Pharmacodynamic Aspects of Cyclobenzaprine and Caffeine in Healthy Subjects and the Effect on Drowsiness Intensity
}

\author{
Ronilson A. Moreno ${ }^{1,2}$, Carlos Eduardo Sverdloff',2, Rogério A. Oliveira ${ }^{2}$, Sandro Evandir Oliveira ${ }^{2}$, \\ Diego Carter Borges ${ }^{3}$, Maristela H. Andraus ${ }^{4}$, Myriam C. Salvadori' ${ }^{4}$, Ney Carter Borges ${ }^{2,5, *}$
}

\author{
'Department of Pharmacology, Faculty of Medical Sciences, State University of Campinas (UNICAMP), \\ PB 6111, 13083-970, Campinas, SP, Brazil, Tel: (0055-19) 3251-9535; Fax: (0055-19) 3289-2968 \\ ${ }^{2}$ Synchrophar Assessoria e Desenvolvimento de Projetos Clínicos S/S Ltda: 24, Cesar Bierrenbach st, \\ Campinas, SP - Brazil. 13015-025, Fax: (19) 3234-2834; E-mail: synchrophar@synchrophar.com \\ ${ }^{3}$ Faculty of Medicine: 250, Francisco Telles st, Jundiai, SP-Brazil. 13202-550, \\ Tel: (0055-11 4587 1095; Fax: (0055-11) 45871095 \\ ${ }^{4}$ ChromAnalysis- MCM Análises Laboratoriais SA, São Paulo-SP, 05019-000, Brazil \\ Tel: +5511 3868-3044; Fax: +5511 3868-4044; E-mail: chromanalysis@uol.com.br \\ ${ }^{5}$ Department of Clinical Medicine, Faculty of Medical Sciences, State University of Campinas \\ (UNICAMP), 13083-970, Campinas, SP, Brazil, Tel: (0055-19) 3521-7098
}

\begin{abstract}
A specific, fast and sensitive LC-MS/MS assay was developed for the determination of cyclobenzaprine in human plasma using imipramine as the internal standard (IS). The limit of quantification was $0.05 \mathrm{ng} / \mathrm{mL}$ and the method was linear in the range of 0.05 to $50 \mathrm{ng} / \mathrm{mL}$. The cyclobenzaprine and IS retention times were $2.74 \pm 0.2 \mathrm{~min}$ and $2.69 \pm 0.2 \mathrm{~min}$, respectively.

Method intra-batch precision and accuracy ranged from 2.90 to $9.72 \%$, and 91.63 to $107.33 \%$, respectively. Interbatch precision ranged from 3.37 to $10.27 \%$, while Interbatch accuracy ranged from 96.13 to $106.10 \%$. The analytical method was applied to evaluate the pharmacokinetic and relative bioavailability of two different pharmaceutical formulations containing cyclobenzaprine, one test tablet containing $10 \mathrm{mg}$ of cyclobenzaprine plus $60 \mathrm{mg}$ of caffeine (Miosan ${ }^{\circledast} /$ cafeine) and the reference Miosan ${ }^{\circledR}$ containing only $10 \mathrm{mg}$ of cyclobenzaprine, manufactured by the same pharmaceutical company. In addition to the pharmacokinetic analysis, a pharmacodinamic evaluation of the drowsiness intensity during the confinement periods was conducted in order to evaluate the caffeine effect. This study evaluated 34 subjects in a randomized, 2-period crossover study with 14 days washout period between doses.
\end{abstract}

Based on the $90 \%$ confidence interval of the individual ratios (test formulation/reference formulation) for $\mathrm{C}_{\max }$ and $\mathrm{AUC}_{\text {inf }}$, it was concluded that the test formulation is bioequivalent to the reference Miosan ${ }^{\circledR}$ with respect to the rate and extent of absorption of cyclobenzaprine and that caffeine had no effect on the relative pharmacokinetic parameters. However, based on the Stanford point analysis, the combination of Miosan ${ }^{\circledR}$ with caffeine in the same tablet formulation significantly decreased the drowsiness intensity observed during the confinement periods.
Keywords: Cyclobenzaprine; Caffeine; Pharmacokinetics; HPLC; Mass spectrometry; Bioavailability

\section{Introduction}

Cyclobenzaprine hydrochloride is a centrally acting muscle relaxant that has been widely used over the past 30 years for relief of muscle spasm associated with acute, painful musculoskeletal conditions (Borenstein et al., 2003; Browning et al., 2001; Katz et al., 1988; Winchell et al., 2002). Disposition studies in humans and laboratory animals have previously shown that cyclobenzaprine hydrochloride is well absorbed (Hucker et al., 1978), is widely distributed among body tissues (Hucker et al., 1978), is subject to enterohepatic circulation (Wang et al., 1996), and is extensively metabolized via both oxidative and conjugative pathways (Hucker et al., 1978).

It is generally prescribed at a dose of $10 \mathrm{mg}$ three times daily and its bioavailability is $33-55 \%(4,5)$. Cyclobenzaprine pharmacokinetics are linear for doses from 2.5 to $10 \mathrm{mg}$ despite the slight deviations from linearity observed at the $5 \mathrm{mg}$ dose (Winchell et al., 2002). Like other tricyclic antidepressants, cyclobenzaprine is also prescribed off-label as a sleep-aid. The sedative effects of cyclobenzaprine are likely due to its antagonistic effect on histamine H1, serotonin 5-HT2A, and muscarinic acetylcholine receptors. Indeed, some studies have confirmed the improvement in sleep quality. For example, a metaanalysis of five published, randomized controlled trials suggests

*Corresponding author: Ney Carter do Carmo Borges, MD, Ph.D., FACC, FACP. 24, Cesar Bierrenbach st, Campinas, SP - Brazil. Zip Code 13015-025, Fax: (19) 3234-2834; E-mail: medney@terra.com.br

Received September 14, 2009; Accepted October 23, 2009; Published October 24, 2009

Citation: Moreno RA, Sverdloff CE, Oliveira RA, Oliveira SE, Borges DC, et al. (2009) Comparative bioavailability and pharmacodynamic aspects of cyclobenzaprine and caffeine in healthy subjects and the effect on drowsiness intensity. J Bioequiv Availab 1: 086-092. doi:10.4172/ jbb.1000013

Copyright: ( $) 2009$ Moreno RA, et al. This is an open-access article distributed under the terms of the Creative Commons Attribution License, which permits unrestricted use, distribution, and reproduction in any medium, provided the original author and source are credited. 


\section{Journal of Bioequivalence \& Bioavailability - Open Access \\ JBB/Vol.1 September-October 2009}

that cyclobenzaprine improves global functioning of patients with fibromyalgia with a modest improvement in sleep quality (Tofferi et al., 2004). In other study conducted with 120 fibromyalgia patients, those receiving Cyclobenzaprine (10 to $40 \mathrm{mg}$ ) over a 12-week period had significantly improved quality of sleep and pain score (Bennett et al., 1988).

The plasma concentration of cyclobenzaprine has been determined by methods using performance liquid chromatography with UV detection (HPLC-UV) (Constanzer et al., 1995) and HPLC method coupled to tandem mass-spectrometric detection (Constanzer et al., 1995; Darwish et al., 2009).

Caffeine is the most widely used stimulant to counteract the effects of sleepiness. Consumption from all sources can be estimated to be approximately $210-238 \mathrm{mg} / \mathrm{day} /$ person in Canada and the US (Barone et al., 1996). Caffeine can be used to increase alertness and performance especially in low action situations such as monotonous highway driving or after sleep deprivation. Moderate doses of caffeine reduce reaction time on performance tasks, improve subjective alertness, and diminish selfreported fatigue and sleepiness (Landolt et al., 2004; Reyner et al., 2000; Van Dongen et al., 2001; Wyatt et al., 2004).

The main objectives of this study were to evaluate the relative bioavailability between the reference Miosan ${ }^{\circledR}(10 \mathrm{mg}$ of ciclobenzaprine) and the test Miosan ${ }^{\otimes} /$ caffeine $(10 \mathrm{mg}$ of ciclobenzaprine $+60 \mathrm{mg}$ of caffeine) formulations, both manufactured by Apsen Farmacêutica S/A (São Paulo, SP, Brazil), and analyze the effect of caffeine in reducing or eliminating the associated side effects of drowsiness caused by cyclobenzaprine. This paper also describes a simple, rapid, sensitive and robust method combining high-performance liquid chromatography (HPLC) and positive electrospray tandem mass spectrometry (HPLC-ESI ${ }^{+} / \mathrm{MS} / \mathrm{MS}$ ) for the cyclobenzaprine quantification in human plasma samples.

\section{Methods}

\section{Subjects}

Eligible subjects were healthy men or women aged 18 to 50 years with a body weight within $15 \%$ of their ideal weight for height (IMC $23.3 \pm 1.9 \mathrm{~kg}$, mean $\pm \mathrm{SD}$, range 19.7 - $26.6 \mathrm{Kg}$ ). The group comprised 34 subjects ( $31.4 \pm 6.5$ years, range $21-44$ years), height between 1.52 and $1.83 \mathrm{~m}(1.67 \pm 0.1 \mathrm{~m})$, weighing between 50.0 and $85.0 \mathrm{~kg}(64.1 \pm 8.0 \mathrm{~kg})$. Subjects were excluded if they had participated in any investigational trial within the previous 4 months; were pregnant or lactating; had a history of substance abuse or recent excessive alcohol consumption; or had hypersensitivity to cyclobenzaprine or any of its excipients. Subjects also were excluded if they were currently using any regular medication within 14 days prior to the first intended dose, except oral contraceptives; or if they tested positive for hepatitis B, hepatitis C, or HIV. Subjects were excluded if they exhibited any concurrent or recent medical condition that might interfere with their ability to participate in the study (eg, hyperthyroidism, uncontrolled cardiac problems, urinary retention, glaucoma, recent surgery); or if they were hospitalized within 8 weeks before the beginning of the study.

Written informed consent was obtained from all subjects before screening.

\section{Study Protocol and Procedures}

This was a randomized, 2-period crossover study with 14 days washout period between doses conducted in Campinas, SP, Brazil and in compliance with the provisions of the Declaration of Helsinki (1964), Tokyo (1975), Venice (1983), Hong Kong (1989), Somerset West (1996), Edinburgh (2000) revisions and the Resolutions No.196/96 and 251/97 of National Health Council - Health Ministry, Brazil. The clinical protocol was also approved by the State University of Campinas Independent Ethic's committee and all participants provided written informed consent.

During each period, the subjects were hospitalized at 6:00 p.m. having an evening meal at 8:30. After an overnight fasting period, the medication started at 7:00 a.m. All doses were administered with $200 \mathrm{~mL}$ of water after a 4-hour fast. All subjects received a single tablet orally corresponding to the test formulation Miosan ${ }^{\otimes} /$ caffeine (MC) formulation containing $10 \mathrm{mg}$ of ciclobenzaprine $+60 \mathrm{mg}$ of caffeine or the reference formulation Miosan ${ }^{\circledR}(\mathrm{M})$ containing only $10 \mathrm{mg}$ of ciclobenzaprine, both produced by Apsen Farmacêutica S/A (São Paulo, SP, Brazil).

All subjects were required to remain fasting at least for four hours after dose when a standard meal was provided after five (lunch), eight (snack) and twelve hours after dosing (evening meal). No other food intake was permitted during the "in-house" period. Liquid consumption was permitted ad libitum six hours before and two hours after drug but caffeine and/or xanthinecontaining drinks including tea, coffee, and cola were prohibited. Food was also xanthine-free. Smoking was prohibited during the "in-house" period. All subjects were requested to stay in the clinic for a $24 \mathrm{~h}$ period after drug administration.

Venous blood samples ( $7.5 \mathrm{~mL}$ each) for the determination of plasma cyclobenzaprine concentrations were collected from an indwelling catheter or by direct venipuncture of an antecubital vein into tubes containing heparin as the anticoagulant. Samples collected for cyclobenzaprine quantification (test and reference formulations) were collected at the following times: $30 \mathrm{~min}$ before dosing and $0.33,0.67,1.0,1.5,2,2.5,3,3.5,4,4.5,5,6,7$, $8,10,14,24,48,72,96,120$, and 144 hours after dosing. Blood samples were placed on ice until centrifuged. Plasma was separated by centrifugation at $3000 \mathrm{rpm}$ for 10 minutes at $2^{\circ} \mathrm{C}$. The plasma was subsequently stored frozen at less than $-5^{\circ} \mathrm{C}$ until analyzed. After the evaluations at 48 hours, subjects were discharged from the study center and were asked to return to the site for the collects at 72, 96, 120 and 144 hours.

\section{Sample Analysis}

Plasma concentrations of cyclobenzaprine were determined by a validated high-performance liquid chromatography (HPLC) method with tandem mass-spectrometric detection in an Applied Biosystems API 5000 (Concord, Ontario, Canada) using ESI+ (positive Electron Spray Ionization). Standard solutions for the analytes were prepared using cyclobenzaprine $\mathrm{HCl}$ (European Pharmacopeia, Batch\# 1) and imipramine as the internal standard (USP, Batch\# 1). Aliquots of $50 \mu \mathrm{L}$ of plasma samples were mixed with $400 \mu \mathrm{L}$ of internal standard working solution (Imipramine $10 \mathrm{ng} / \mathrm{mL}$ ) in acetonitrile and vortex-mixed for $15 \mathrm{sec}$ onds. Next, samples were centrifuged at $5000 \mathrm{rpm}$ for $3 \mathrm{~min}-$ 


\section{Journal of Bioequivalence \& Bioavailability - Open Access \\ JBB/Vol.1 September-October 2009}

utes. The supernatant was transferred to a clean tube and 600 $\mu \mathrm{L}$ of $\left.\mathrm{AcN}-\mathrm{H}_{2} \mathrm{O}\right)$ (1:1) were added. After homogenization, 100 $\mu \mathrm{L}$ were transferred to a 96-well plate for injection.

Chromatographic separation was performed by an Agilent model 1100 HPLC system (Santa Clara, CA, USA) using a C18 $4.0 \times 3 \mathrm{~mm}$ Phenomenex (Torrance, CA, USA) guard column and a Agilent Zorbax Eclipse XDB (Santa Clara, CA, USA) C8 $150 \times 4.6 \mathrm{~mm}(5 \mu \mathrm{m})$ column, under a flow of $0.80 \mathrm{~mL} / \mathrm{min}$.

The mass spectrometer equipped with electrospray ionization (ESI) source was operated in the positive ion mode (ES+) and multiple reactions monitoring (MRM) mode. The tuning parameters were optimized for cyclobenzaprine and imipramine by infusing the standard solution of each compound into the stainless steel sample capillary of the electrospray source. The capillary voltage was set to $4000 \mathrm{~V}$ and Nitrogen was used as drying gas for solvent evaporation at $600^{\circ} \mathrm{C}$. The collision energies were 57 and $55 \mathrm{eV}$ for cyclobenzaprine and imipramine, respectively. Based on the full scan MS/MS spectrum of each drug, the most abundant ions were selected and the mass spectrometer was set to monitor the transitions of the precursors to the product ions. The mass transitions monitored were $276.3>215.1$ for cyclobenzaprine and 281.2>193.0 for imipramine, respectively. The dwell time was set to $225 \mathrm{msec}$ for both transitions.

The standard calibration curves were constructed using the peak area ratios of cyclobenzaprine and IS versus the cyclobenzaprine nominal concentrations of the eight plasma standards $(0.05,0.10,0.50,1.00,5.00,10.00,30.00$ and $50.00 \mathrm{ng} /$ $\mathrm{mL}$ ) in duplicate. Linear least-square regression analysis, with weighting factor of $1 / \mathrm{x}^{2}$, was performed to assess the linearity, as well as to generate the standard calibration equation: $y=a x+$ $b$, where $y$ is the peak-area ratio, $x$ the concentration, $a$ the slope and $b$ is the intercept of the regression line. In addition, a blank (non-spiked sample) and a zero plasma sample (only spiked with IS) were run to demonstrate the absence of interferences.

\section{Pharmacokinetic Analysis}

Bioequivalence between the two formulations was assessed by calculating individual test/reference ratios for the peak of concentration $\left(\mathrm{C}_{\max }\right)$, area under the curve (AUC) of plasma concentration until the last concentration observed $\left(\mathrm{AUC}_{\text {last }}\right)$ and the area under the curve between the first sample (pre-dosage) and infinite $\left(\mathrm{AUC}_{\mathrm{inf}}\right) . \mathrm{C}_{\max }$ and the time taken to achieve this concentration $\left(\mathrm{T}_{\max }\right)$ were obtained directly from the curves. The areas under the cyclobenzaprine plasma concentration versus time curves from 0 to the last detectable concentration $\left(\mathrm{AUC}_{\text {last }}\right)$ were calculated by applying the linear trapezoid rule. Statistical calculations were defined at the level of $P \leq 0.05$ and bioequivalence for test and reference formulations was concluded as the $90.0 \%$ confidence interval for $\mathrm{C}_{\text {max }}, \mathrm{AUC}_{\text {last }}$ and $\mathrm{AUC}_{\text {inf }}$ within the range of 80.0-125.0\% defined by both the Food and Drug Administration (FDA) and the National Sanitary Surveillance Agency (ANVISA). The software used included Winnonlin ${ }^{\circledR}$ 2.0, MS Excel ${ }^{\circledR}$ 2003, Graph Pad Prism v 4.

\section{Pharmacodynamic Aspects}

The comparison of the pharmacodinamic aspects after administration of both test (MC) and reference (M) formulations was studied by the evaluation of the drowsiness intensity during the confinement.
Initially, the residual interference between the two periods of confinement was evaluated; then, the direct effect of the treatment over drowsiness intensity was determined. Finally, the time correlation with the formulation administration was also evaluated using three different time observations. The intensity of the effect was quantified based on the Stanford Sleepiness Scale at 1:30h (T1), 3:30h (T2) and 5:00h (T3) after drug administration. In order to verify the residue interference between periods, the mean values obtained from the Stanford Sleepiness Scale on T1, T2 and T3 were calculated for each group in each confinement period. The residue effect over confinement was calculated using the ANOVA test with two factors (group and confinement), considering that the factor confinement contained repeated measures.

In addition, a brief survey questionnaire consisting of a few questions about the drowsiness effect in each study period was applied. In this case, the comparison between the formulations was performed using the chi-square analysis to study the response proportion for each treatment. The analysis were performed using the software Minitab 15.0 with a significance level of $5 \%(\alpha=0.05)$.

\section{Results}

\section{Method Validation}

The simplest regression method for the calibration curves of the cyclobenzaprine was $Y=a+b x$ from 0.05 to $50 \mathrm{ng} / \mathrm{mL}$ and the correlation coefficient ranged from 0.9951 to 0.9983 (mean $=0.9974$ )

A)

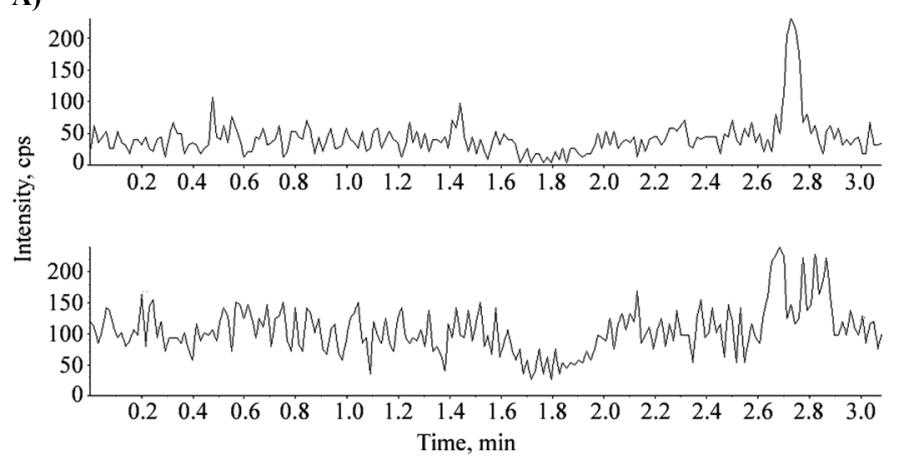

B)

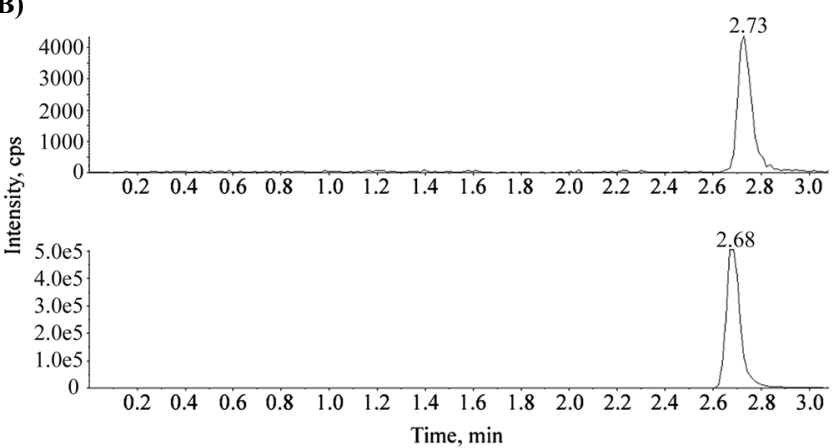

Figure 1: Cyclobenzaprine and imipramine chromatograms after extraction from human plasma. The mass transitions monitored for the analytes were $276.3>215.1$ for cyclobenzaprine (upper panel) and 281.2 > 193.0 for imipramine (lower panel). The analysis was performed in extracted blank plasma (a) or in spiked blank plasma at cyclobenzaprine LLOQ $(0.05 \mathrm{ng} / \mathrm{mL})$ concentration (b).

J Bioequiv Availab
Volume 1(3): 086-092 (2009) - 088 


\section{Journal of Bioequivalence \& Bioavailability - Open Access \\ JBB/Vol.1 September-October 2009}

The chromatograms obtained from LLOQ $(0.05 \mathrm{ng} / \mathrm{mL})$ and extracted blank plasma are presented in Figure 1. The cyclobenzaprine and IS retention times were $2.74 \pm 0.2 \mathrm{~min}$ and $2.69 \pm 0.2 \mathrm{~min}$, respectively. The signal-to-noise ratio was higher than 7 .

In the case of cyclobenzaprine and its IS there was no significant ion suppression in the retention times where they are eluted. There was no suppression when the analysis was performed using blank normal plasma (Figure 2).

After analysis of the three QC levels (0.15, 20 and $40 \mathrm{ng}$ / $\mathrm{mL}$ ), cyclobenzaprine showed the mean recovery (values \pm

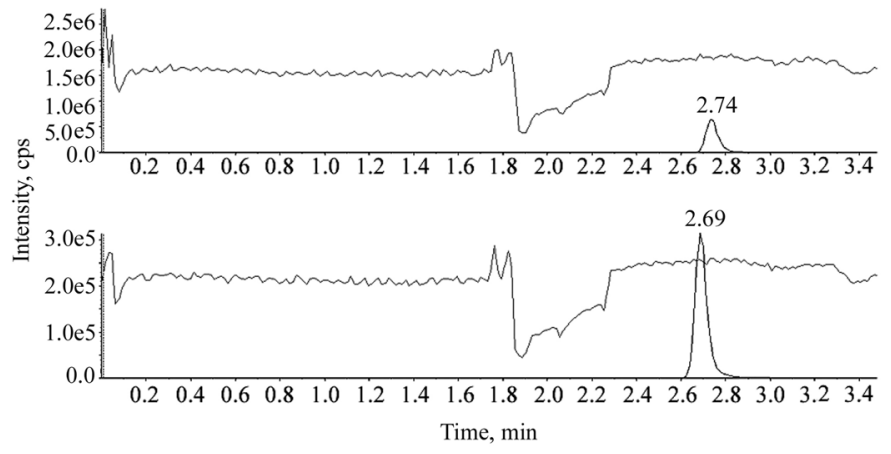

Figure 2: Ion suppression in normal blank plasma. The mass transitions monitored for the analytes were $276.3>215.1$ for cyclobenzaprine (upper panel) and 281.2 > 193.0 for imipramine (lower panel).
$\mathrm{CV}(\%), \mathrm{n}=5)$ of $82.27 \pm 14.97 \%$ and the IS recovery was 92.43 $\pm 5.5 \%$.

Intra-batch precision and accuracy of the assay was measured for cyclobenzaprine at each QC level as presented in Table 1. These results were within the acceptance criteria for precision and accuracy, i.e., deviation values were within $\pm 15 \%$ of the nominal values, except for the LLOQ which could show a $\pm 20 \%$ deviation.

Stability tests indicated that there was no significant degradation of the stock solution. The variation between fresh and stored samples was -8.0 and $7.9 \%$ for cyclobenzaprine and IS respectively, after 1 day at $4.0 \pm 2.0^{\circ} \mathrm{C}$. In addition, the variations between fresh and frozen samples after 8 days were 1.4 and $3.7 \%$ for cyclobenzaprine and IS, respectively.

The stability of cyclobenzaprine was assessed in spiked human plasma and this analyte showed no significant degradation after $7 \mathrm{~h}$ at room temperature, three freeze/thaw cycles, $48 \mathrm{~h}$ post processing or 192 days at $-20^{\circ} \mathrm{C}$ (Table 2 ).

\section{Comparative Pharmacokinetic Study}

Cyclobenzaprine was well tolerated at the administered doses and no significant adverse reactions were observed or reported. No clinically relevant changes were observed in any measured biochemical parameter. A total of 34 subjects finished the study. The mean cyclobenzaprine plasma concentration versus time curves obtained after a single oral dose of each formulation is shown in Figure 3. The plasma concentration of cyclobenzaprine

\begin{tabular}{|l|c|c|c|c|c|}
\hline $\begin{array}{l}\text { QC } \\
\text { samples }\end{array}$ & $\begin{array}{c}\text { Nominal } \\
\text { concentration } \\
(\mathrm{ng} / \mathrm{mL})\end{array}$ & $\begin{array}{c}\text { Intra-run } \\
\text { accuracy }^{\mathrm{a}} \\
(\%)\end{array}$ & $\begin{array}{c}\text { Inter-run }_{\text {accuracy }^{\mathrm{b}}} \\
(\%)\end{array}$ & $\begin{array}{c}\text { Intra-run precision }^{\mathrm{c}} \\
(\% \mathrm{CV})\end{array}$ & $\begin{array}{c}\text { Inter-run }^{\text {precision }}{ }^{\mathrm{b}} \\
(\% \mathrm{CV})\end{array}$ \\
\hline QC-LLOQ & 0.05 & 91.63 & 96.13 & 9.72 & 10.27 \\
\hline QCL & 0.15 & 100.29 & 101.78 & 4.62 & 7.22 \\
\hline QCM & 20.0 & 107.33 & 106.10 & 2.90 & 3.37 \\
\hline QCH & 40.0 & 106.36 & 104.18 & 6.14 & 4.92 \\
\hline
\end{tabular}

a $(n=6)$, expressed as (found concentration / nominal concentration) x 100

${ }^{b}$ Values obtained from all 3 runs $(n=18)$

${ }^{c} n=6$

Table 1: Accuracy and precision data for cyclobenzaprine quantification in human plasma.

\begin{tabular}{|c|c|c|c|c|c|}
\hline & Initial mean conc. $(\mathrm{ng} / \mathrm{mL})$ & $\% \mathrm{CV}$ & $\begin{array}{c}\text { Final mean conc. } \\
(\mathrm{ng} / \mathrm{mL})\end{array}$ & $\% \mathrm{CV}$ & Variation $(\%)$ \\
\hline \multicolumn{6}{|c|}{ Freeze/thaw stability test ( 3 cycles) } \\
\hline QCL & 0.16 & 4.2 & 0.14 & 6.5 & -10.9 \\
\hline $\mathrm{QCH}$ & 45.38 & 2.5 & 38.64 & 3.5 & -14.8 \\
\hline \multicolumn{6}{|c|}{ Short Term stability test $(7 \mathrm{~h})$} \\
\hline QCL & 0.16 & 3.9 & 0.16 & 3.6 & -0.5 \\
\hline $\mathrm{QCH}$ & 38.64 & 1.7 & 38.40 & 1.8 & -0.6 \\
\hline \multicolumn{6}{|c|}{ Post Processing stability test $(48 \mathrm{~h})$} \\
\hline QCL & 0.16 & 3.9 & 0.16 & 4.4 & 1.8 \\
\hline $\mathrm{QCH}$ & 38.64 & 1.7 & 38.26 & 1.7 & -1.0 \\
\hline \multicolumn{6}{|c|}{ Long Term stability test (192 days, $\left.-20^{\circ} \mathrm{C}\right)$} \\
\hline QCL & 0.16 & 1.7 & 0.14 & 5.9 & -13.5 \\
\hline $\mathrm{QCH}$ & 42.54 & 3.9 & 42.24 & 3.8 & -0.7 \\
\hline
\end{tabular}

$\mathrm{n}=5$ for each test.

$\mathrm{QCL}=0.15 \mathrm{ng} / \mathrm{mL} ; \mathrm{QCH}=40 \mathrm{ng} / \mathrm{mL}$

Tabel 2: Stability tests of cyclobenzaprine in human plasma. 


\section{Journal of Bioequivalence \& Bioavailability - Open Access \\ JBB/Vol.1 September-October 2009}

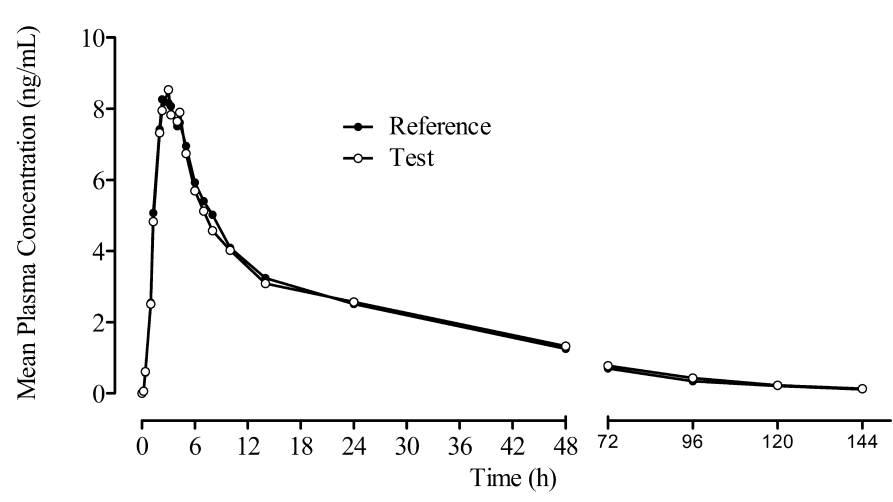

Figure 3: Cyclobenzaprine comparative pharmacokinetics. Mean cyclobenzaprine plasma concentration versus time curves obtained after a single oral dose of test (Miosan ${ }^{\circledR} /$ caffeine) and reference $\left(\right.$ Miosan $\left.^{\circledR}\right)$ formulations to 34 subjects.

\begin{tabular}{|l|c|c|c|c|}
\hline \multirow{2}{*}{} & \multicolumn{2}{|c|}{$\begin{array}{c}\text { Test } \\
\text { formulation }\end{array}$} & \multicolumn{2}{c|}{$\begin{array}{c}\text { Reference } \\
\text { formulation }\end{array}$} \\
\cline { 2 - 5 } & Mean & SD & Mean & SD \\
\hline $\begin{array}{l}\mathrm{C}_{\max } \\
(\mathrm{ng} / \mathrm{mL})\end{array}$ & 9.38 & 3.14 & 10.08 & 3.29 \\
\hline $\mathrm{T}_{\max }(\mathrm{h})$ & 3.04 & 1.03 & 3.25 & 1.05 \\
\hline $\mathrm{T}_{1 / 2}(\mathrm{~h})$ & 26.46 & 6.44 & 26.08 & 7.63 \\
\hline $\begin{array}{l}\mathrm{AUC} \\
([\mathrm{ng} x\end{array}$ & 189.59 & 65.54 & 191.51 & 71.31 \\
$\mathrm{~h}] / \mathrm{mL})$ & 197.84 & 73.29 & 198.13 & 77.46 \\
\hline $\begin{array}{l}\mathrm{AUCC} \\
([\mathrm{ng} x \\
\mathrm{h}] / \mathrm{mL})\end{array}$ & & & & \\
\hline
\end{tabular}

Table 3: Arithmetic mean pharmacokinetic parameters obtained from 34 volunteers after administration of the test formulation Miosan ${ }^{\circledR} /$ caffeine formulation containing $10 \mathrm{mg}$ of ciclobenzaprine $+60 \mathrm{mg}$ of caffeine or the reference formulation Miosan ${ }^{\circledR}$ containing $10 \mathrm{mg}$ of ciclobenzaprine only.

\begin{tabular}{|l|l|c|c|c|}
\hline \multirow{2}{*}{ Parameters } & \multicolumn{4}{|c|}{ Parametric (n=34) } \\
\cline { 2 - 5 } & $\begin{array}{c}\text { Geometric } \\
\text { mean (\%) }\end{array}$ & $90 \%$ CI & $\begin{array}{c}\text { Power } \\
(\%)\end{array}$ & $\begin{array}{c}\text { CV } \\
(\%)\end{array}$ \\
\hline $\begin{array}{l}\text { AUC } \\
\text { ratio }\end{array}$ & 98.90 & $93.17-104.99$ & 99 & 14.60 \\
\hline $\begin{array}{l}\text { AUC } \\
\text { ratio }\end{array}$ & 99.67 & $94.12-105.54$ & 99 & 14.00 \\
\hline $\begin{array}{l}\mathrm{C}_{\text {max }} \% \\
\text { ratio }\end{array}$ & 92.82 & $86.47-99.63$ & 99 & 17.37 \\
\hline
\end{tabular}

Table 4: Geometric mean of the individual AUClast, AUC0inf and $C$ max ratios (test/reference formulation) and the respective $90 \%$ CIs.

did not differ significantly after administration of both formulations (test formulation and the reference one).

Table 3 shows the values of the pharmacokinetic parameters and Table 4 summarizes the bioequivalence analysis for cyclobenzaprine formulations. Briefly, the geometric mean and respective $90 \%$ confidence intervals of cyclobenzaprine test/ reference percent ratios were $92.82 \%(86.47-99.63 \%)$ for $\mathrm{C}_{\max }$, 98.90\% (93.17 - 104.99\%) for $\mathrm{AUC}_{\text {last }}$ and 99.67\% (94.12 $105.54 \%$ ) for $\mathrm{AUC}_{\mathrm{inf}}$. These $90 \%$ confidence intervals for geometric mean ratios were within the acceptable limits (80-125\%) of bioequivalence. The test and reference formulations were considered bioequivalent.

\section{Pharmacodynamic Aspects}

The mean of the drowsiness score obtained in each period was 5.0 for period 1 and 5.1 for period 2. The ANOVA results showed no residue effect throughout the two confinement periods $(\mathrm{p}=0.716)$.

In each period, the group that received the test formulation

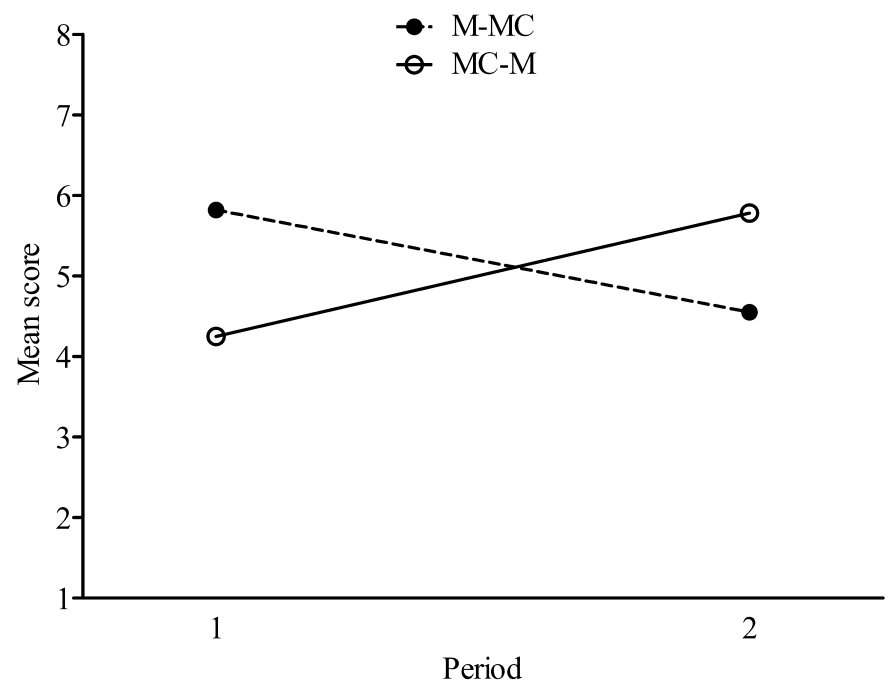

Figure 4: Mean drawsiness score during the confinement periods 1 and 2. Half of the subjects received the test formulation Miosan ${ }^{\circledR} /$ caffeine MC) or the reference Miosan ${ }^{\circledR}(\mathrm{M})$ in the period 1 and inverted in the period 2. For the statistical purposes subjects were analyzed in two groups, accordingly to the formulation sequence adopted in the confinement periods: MC$\mathrm{M}$ and $\mathrm{M}-\mathrm{MC}$.

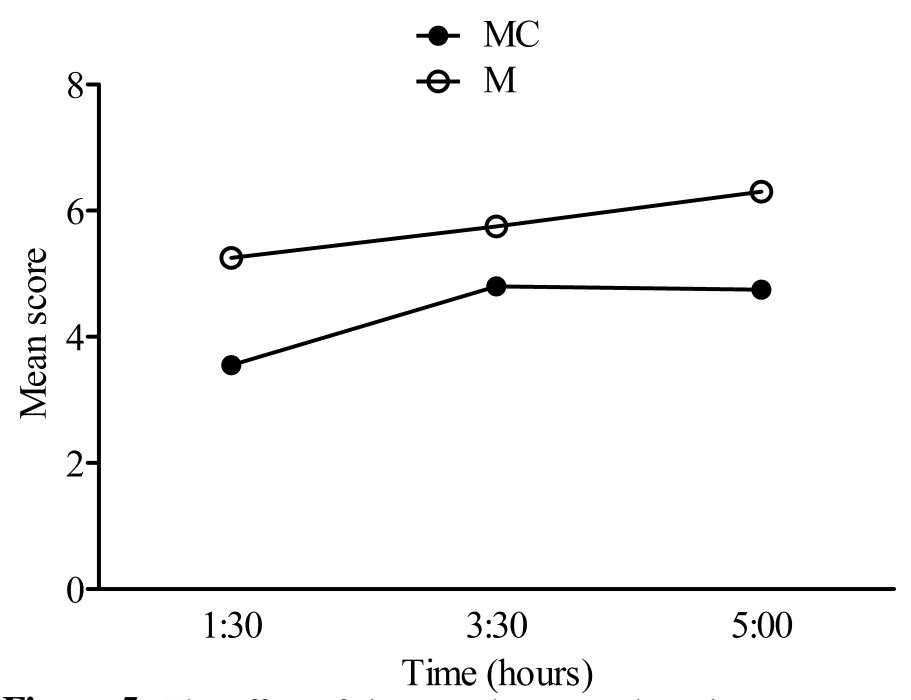

Figure 5: The effect of time on the mean drowsiness score. Half of the subjects received the formulation Miosan ${ }^{\circledR} /$ caffeine (MC) or the Miosan ${ }^{\circledR}(\mathrm{M})$ in the period 1 and inverted in the period 2. Results from period 1 and 2 were grouped for the same formulation and expressed as MC or M scores. Only the drowsiness score observed after 5:00h was significantly $(\mathrm{p}<0.001)$ more intense than that observed at 1:30h. The comparison between the closest time points (1:30 to $3: 30 \mathrm{~h}$ and $3: 30$ to $5: 00 \mathrm{~h}$ ) showed no statistical significance. 


\section{Journal of Bioequivalence \& Bioavailability - Open Access \\ JBB/Vol.1 September-October 2009}

(Miosan ${ }^{\circledR} /$ caffeine) showed a drowsiness score significantly $(\mathrm{p}<0,001)$ lower than that obtained with the group that received the reference Miosan ${ }^{\circledR}$ formulation (Figure 4). The mean score for the subjects group receiving the test formulation was 4.4, while the mean score for the reference was 5.8 Stanford points.

Using the multiple comparison analysis (Turkey method), it was determined that the drowsiness observed after 5:00h was more intense than that observed at $1: 30 \mathrm{~h}(\mathrm{p}<0.001)$ (Figure 5). However, the comparison between the closest time points (1:30 to $3: 30 \mathrm{~h}$ and $3: 30$ to $5: 00 \mathrm{~h}$ ) showed no statistical significance.

During the analysis about the subject perception of drowsiness, all 34 subjects were evaluated and 27 (79.4\%) informed a more intense drowsiness during the administration of Miosan ${ }^{\circledR}$ formulation and only 6 (17.6\%) informed a more intense drowsiness during the administration of Miosan ${ }^{\circledR} /$ caffeine formulation. One subject informed no difference between the periods. These results were statically significant after chi-square analysis $(\mathrm{p}<0,001)$.

\section{Disucssion}

The LC-MS/MS method described here for drug quantification is in accordance with both Food and Drug Administration (FDA) and the National Sanitary Surveillance Agency (ANVISA) requirements for pharmacokinetic studies.

The sample preparation method described in this work is based on a simple liquid-liquid extraction. Blank plasma samples from all 34 subjects showed a clear chromatogram in all cases. The extraction method was sufficient to providing a clean extracted and a reproducible quantification allied to the high selectivity of the MRM mode on LC-APPI-MS/MS spectrometer. This method offers advantages over those previously reported since it used a lower amount of plasma $(50 \mu \mathrm{l})$, significantly lower than the $250 \mu \mathrm{l}$ used by Darwish et al., (2009) and the $1000 \mu \mathrm{l}$ used by Constanzer et al., (1995). In addition, our method is associated with a faster chromatographic run time (2.5 min) compared to the previously $15 \mathrm{~min}$ reported by (Constanzer et al., 1995).

The method provides excellent analytical performance for cyclobenzaprine extraction and proved to be appropriate for analyzing human plasma samples. The reported LLOQ $0.05 \mathrm{ng} /$ $\mathrm{mL}$ is lower than the $0.1 \mathrm{ng} / \mathrm{mL}$ described by (Constanzer et al., 1995) and the $0.5 \mathrm{ng} / \mathrm{mL}$ method described by (Darwish et al., 2009). The reported analytical method has been successfully applied to human pharmacokinetic investigations and bioequivalence was confirmed by the $90 \%$ Confidence Interval for the ratios of the $\mathrm{C}_{\max }$ and $\mathrm{AUC}_{\text {last }}$ values being within the acceptance range of $80-125 \%$.

After evaluation of the formulations effect on the drowsiness during the pharmacokinetics study, the ANOVA analysis of the drowsiness score obtained in each period showed that there is no residue effect through the two confinement periods $(\mathrm{p}=0.716)$, confirming that the results obtained in the second period does not depend on the formulation used in the first confinement period. However, when the direct effect of the treatment over drowsiness was evaluated to clarify the differences between the two formulations, it was observed that there is a statically significant difference $(\mathrm{p}<0,001)$ between the groups. In each pe- riod, the group that received the test formulation Miosan ${ }^{\circledR} /$ caf- $^{-}$ feine showed drowsiness score significantly lower than the one obtained with the group that received the reference formulation Miosan ${ }^{\circledR}$.

In the analysis of the time effect the results showed no interaction between time and formulation $(\mathrm{p}=0.416)$, since both formulations presented a similar behavior during the time analyzed. However, a time effect was observed in both formulations, meaning that the analysis performed at the three time points showed different drowsiness levels $(\mathrm{p}<0.001)$. However, the statistic significance was observed only between the extreme time points (1:30 and 5:00h). The Stanford point's analysis was corroborated by the evaluation of the subject drowsiness perception. After a direct questioning, a clear statistical significance was obtained $(p<0,001)$ since $79.4 \%$ of the subjects declared a more intense drowsiness during the administration of reference formulation containing only cyclobenzaprine and only $17.6 \%$ declared a more intense drowsiness during the administration of test formulation containing cyclobenzaprine and caffeine.

The effect of cyclobenzaprine effect on sleep physiology is well described in the literature. For example, Bennett et al., (1988) showed that in a study of 120 fibromyalgia patients, those receiving cyclobenzaprine ( 10 to $40 \mathrm{mg}$ ) over a 12 -week period had significantly improved quality of sleep and pain score. There was also a reduction in the total number of tender points and muscle tightness. Reynolds et al., (1991) performed a crossover designed study to exam the overnight sleep physiology, pain, fatigue, and mood symptoms in 12 patients with fibromyalgia treated with cyclobenzaprine. Patients receiving cyclobenzaprine showed a significant decrease in evening fatigue and an significant increase in total sleep time. More recently, Tofferi et al., (2004) showed that cyclobenzaprine-treated patients were 3 times as likely to report overall improvement and to report moderate reductions in individual symptoms, particularly sleep.

In addition, caffeine is often used to counteract sleepiness generated by sleep deprivation, jet lag, and shift-work. Recently, Carrier et al., (2007) performed a study with thirty-four moderate caffeine consumers in both caffeine $(200 \mathrm{mg})$ and placebo (lactose) conditions in a double-blind crossover design. Compared to placebo, caffeine lengthened sleep latency, increased stage 1, reduced stage 2 and slow-wave sleep in both groups. The authors also concluded that the main effects of caffeine are on daytime recovery sleep compared to nocturnal sleep. In an even more recent work, Carrier et al., (2009) studied the combined influence of age and caffeine and concluded that the sleep of middle-aged subjects are particularly vulnerable to the circadian waking signal and proposed that lower brain synchronization due to age and caffeine produces greater difficulty in overriding the circadian waking signal during daytime sleep and leads to fragmented sleep.

Michael et al., (2008) studied the effects of a capsule containing $200 \mathrm{mg}$ of caffeine in twelve non-sleep-deprived participants. The author observed that caffeine reduced the Johns Drowsiness Scale score and reaction times, and these changes persisted for 3 to $4 \mathrm{~h}$. They concluded that despite being well rested, administration of caffeine significantly increased alertness and enhanced performance. 


\section{Journal of Bioequivalence \& Bioavailability - Open Access \\ JBB/Vol.1 September-October 2009}

\section{Conclusion}

This work describes a fast, sensitive and robust method to quantify cyclobenzaprine in human plasma in conformity with the requirements proposed by the US Food and Drug Administration for pharmacokinetic assays such as bioequivalence studies. The described method was successfully applied in a bioequivalence study of two cyclobenzaprine $10 \mathrm{mg}$ tablet formulations using an open, randomized, two-period crossover design. Since the $90 \% \mathrm{CI}$ for $\mathrm{C}_{\text {max }}$ and AUC ratios were all inside the $80-125 \%$ interval, it was concluded that the test formulation of cyclobenzaprine is bioequivalent to the reference formulation with respect to both the rate and the extent of absorption and that caffeine present in the test formulation had no effect on the cyclobenzaprine pharmacokinetics.

There is a statically significant difference between the effects of each formulation on the subject drowsiness. Since the drowsiness score was significantly lower when the formulation Miosan ${ }^{\circledast} /$ caffeine was administrated in comparison with the results obtained after administration of the Miosan ${ }^{\circledR}$ formulation, it was concluded that combination of Miosan ${ }^{\circledR}$ with caffeine in the same tablet formulation significantly decreases the drowsiness intensity.

\section{Acknowledgment}

Authors sincerely ackwnoledge Apsen Farmacêutica S.A. for providing the drugs and financial assistance for the execution of the study.

\section{References}

1. Barone JJ, Roberts HR (1996) Caffeine consumption. Food Chem Toxicol 34: 119-129.» CrossRef » Pubmed » Google Scholar

2. Bennett RM, Gatter RA, Campbell SM, Andrews RP, Clark SR, et al. (1988) A comparison of cyclobenzaprine and placebo in the management of fibrositis. A double-blind controlled study. Arthritis Rheum 31: 1535-1542. "CrossRef » Pubmed » Google Scholar

3. Borenstein DG, Korn S (2003) Efficacy of a low-dose regimen of cyclobenzaprine hydrochloride in acute skeletal muscle spasm: results of two placebo-controlled trials. Clin Ther 25: 1056-1073. " CrossRef » Pubmed » Google Scholar

4. Browning R, Jackson JL, O’Malley PG (2001) Cyclobenzaprine and back pain: a meta-analysis. Arch Intern Med 161: 1613-1620. » CrossRef » Pubmed » Google Scholar

5. Carrier J, Fernandez-Bolanos M, Robillard R, Dumont M, Paquet J, et al. (2007) Effects of caffeine are more marked on daytime recovery sleep than on nocturnal sleep. Neuropsychopharmacology 32: 964-972.» CrossRef » Pubmed " Google Scholar

6. Carrier J, Paquet J, Fernandez-Bolanos M, Girouard L, Roy J, et al. (2009) Effects of caffeine on daytime recovery sleep: A double challenge to the sleep-wake cycle in aging. Sleep Med 10:1016-24.» CrossRef » Pubmed » Google Scholar

7. Constanzer M, Chavez C, Matuszewski B (1995) Development and comparison of high-performance liquid chromato- graphic methods with tandem mass spectrometric and ultraviolet absorbance detection for the determination of cyclobenzaprine in human plasma and urine. J Chromatogr B Biomed Appl 666: 117-126.» CrossRef » Pubmed » Google Scholar

8. Darwish M, Chang S, Hellriegel ET (2009) A pharmacokinetic comparison of single doses of once-daily cyclobenzaprine extended-release $15 \mathrm{mg}$ and $30 \mathrm{mg}$ : a randomized, double-blind, two-period crossover study in healthy volunteers. Clin Ther 31: 108-114. \ " CrossRef » Pubmed » Google Scholar

9. Hucker HB, Stauffer SC, Balletto AJ, White SD, Zacchei AG, et al. (1978) Physiological disposition and metabolism of cyclobenzaprine in the rat, dog, rhesus monkey, and man. Drug Metab Dispos 6: 659-672»" CrossRef » Pubmed » Google Scholar

10. Katz WA, Dube J (1988) Cyclobenzaprine in the treatment of acute muscle spasm: review of a decade of clinical experience. Clin Ther 10: 216-228. " Pubmed » Google Scholar

11. Landolt HP, Retey JV, Tonz K, Gottselig JM, Khatami R, et al. (2004) Caffeine attenuates waking and sleep electroencephalographic markers of sleep homeostasis in humans. Neuropsychopharmacology 29: 1933-1939.

" CrossRef » Pubmed " Google Scholar

12. Michael N, Johns M, Owen C, Patterson J (2008) Effects of caffeine on alertness as measured by infrared reflectance oculography. Psychopharmacology (Berl) 200: 255-260. " CrossRef » Pubmed » Google Scholar

13. Reyner LA, Horne JA (2000) Early morning driver sleepiness: effectiveness of $200 \mathrm{mg}$ caffeine. Psychophysiology 37: 251-256. " CrossRef » Pubmed » Google Scholar

14. Reynolds WJ, Moldofsky H, Saskin P, Lue FA (1991) The effects of cyclobenzaprine on sleep physiology and symptoms in patients with fibromyalgia. J Rheumatol 18: 452454. » CrossRef » Pubmed » Google Scholar

15. Tofferi JK, Jackson JL, O’Malley PG (2004) Treatment of fibromyalgia with cyclobenzaprine: A meta-analysis. Arthritis Rheum 51: 9-13. " CrossRef » Pubmed » Google Scholar

16. Van Dongen HP, Price NJ, Mullington JM, Szuba MP, Kapoor SC, et al. (2001) Caffeine eliminates psychomotor vigilance deficits from sleep inertia. Sleep 24: 813-819. » CrossRef » Pubmed » Google Scholar

17. Wang RW, Liu L, Cheng H (1996) Identification of human liver cytochrome $\mathrm{P} 450$ isoforms involved in the in vitro metabolism of cyclobenzaprine. Drug Metab Dispos 24: 786791. » CrossRef » Pubmed » Google Scholar

18. Winchell GA, King JD, Chavez-Eng CM, Constanzer ML, Korn SH (2002) Cyclobenzaprine pharmacokinetics, including the effects of age, gender, and hepatic insufficiency. J Clin Pharmacol 42: 61-69.» CrossRef » Pubmed » Google Scholar

19. Wyatt JK, Cajochen C, Ritz-De CA, Czeisler CA, Dijk DJ (2004) Low-dose repeated caffeine administration for circadian-phase-dependent performance degradation during extended wakefulness. Sleep 27: 374-381. » CrossRef » Pubmed » Google Scholar 